Vol 2 No 1 (2019) 18-42 P-ISSN 2620-295 E-ISSN 2747-0490

DOI: 1047467/elmal.v1i1.313

\title{
Pengaruh Pendistribusian Dana Zakat Produktif terhadap Tingkat Pendapatan Mustahik di DPU Daarut Tauhid Bogor
}

\author{
Anggia Safitri \\ Program Studi Ekonomi Syariah dan Fakultas Syariah. \\ Riyanto \\ Institut Agama Islam Nasional Laa Roiba Bogor \\ riyanto.bcm@gmail.com \\ Dessy Damayanthy \\ Institut Agama Islam Nasional Laa Roiba Bogor \\ dessydamayanthy@laaroiba.ac.id \\ Dedi Junaedi \\ Masyarakat Ekonomi Syariah (MES) Bogor \\ dedijunaedi@mes-bogoraya.net
}

\begin{abstract}
Lembaga Amil Zakat Dompet Peduli Ummat Daarut Tauhiid (DPU DT to contribute to community empowerment in the economic field, Education, preaching, humanity and social. This research is motivated by the problem of how to distribute or distribution of productive zakat funds to the level of economic income mustahik. Seeing the problems experienced by mustahik better than before and after becoming a mustahik, with the empowerment of this productive zakat mustahik is expected to be able to run his business continuously so that increase economic income. This research is a descriptive-quantitative research using the Simple Linear Regression method. Sample in research this amounted to 20 respondents. Data collection using a questionnaire and Data processing using analysis tools SPSS Version 26.0, research result shows that the distribution of productive zakat funds has an effect on Mustahik's income level is 61.1\%, while the rest are influenced by another factor of 38.9\%. Therefore, Productive zakat distribution in Business capital by DPU DT Bogor Branch can be increased.
\end{abstract}

18 | Vomule 2 Nomor 12019 


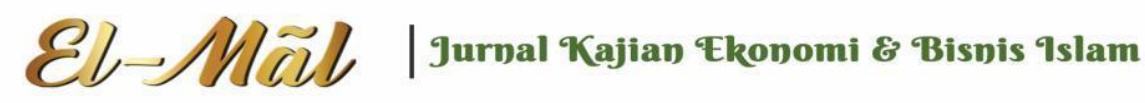

Vol 2 No 1 (2019) 18-42 P-ISSN 2620-295 E-ISSN 2747-0490

DOI: $1047467 /$ elmal.v1i1.313

\title{
Keywords : Productive Zakat, Mustahik, Zakat Fund Distribution, Income Level
}

\begin{abstract}
ABSTRAK
Lembaga Amil Zakat Nasional Dompet Peduli Ummat Daarut Tauhiid (DPU DT) dibentuk untuk berkontribusi memberdayakan masyarakat dalam bidang ekonomi, pendidikan, dakwah, kemanusiaan dan social. Penelitian ini merupakan penelitian deskriptif-kuantitatif dengan menggunakan metode regresi linear sederhana. Pengumpulan data menggunakan kuesioner dan pengolahan data menggunakan alat analisis SPSS Versi 26.0. Hasil penelitian menunjukkan bahwa pendistribusian dana zakat produktif berpengaruh terhadap tingkat pendapatan mustahik sebesar $61,1 \%$, sedangkan sisanya dipengaruhi oleh factor lain sebesar 38,9\%. Oleh karena itu, pendistribusian zakat produktif dalam modal usaha oleh DPU DT Cabang Bogor dapat ditingkatkan secara berkelanjutan.
\end{abstract}

\section{Kata Kunci : Zakat Produktif, Mustahik, Pendistribusian Dana Zakat, Tingkat Pendapatan}

\section{PENDAHULUAN}

Zakat adalah salah satu rukun islam yang wajib di penuhi oleh setiap muslim, yang mana satu-satunya dalam rukun islam yang mempunyai dua keterkaitan yaitu habluminallah dan habluminannas. Artinya zakat menjadi perwujudan ibadah seseorang hamba kepada Allah SWT sekaligus perwujudan kepedulian sosial oleh masyarakat muslim, dengan menyisihkan sebagian harta yang dimiliki untuk dibagikan kepada Mustahiq. Zakat merupakan sebuah solusi untuk tolong menolong sesama umat islam dan menuntaskan suatu kemiskinan, karena dengan zakat mampu mengubah orang yang tadinya mustahik menjadi muzakki. (Abdurrachman Qadir, 2001).

Zakat merupakan ibadah maliyahn ijtima'iyyah (bersifat material dan social). Dengan kata lain bahwa zakat mempunyai dua dimensi yaitu dimensi material dan social yang sangat penting bagi kehidupan manusia. (Qardawi, 1993). Zakat mempunyai manfaat yang sangat besar baik bagi 
DOI: $1047467 /$ elmal.v1i1.313

muzakki maupun mustahiq, bagi harta maupun masyarakat secara umum. (Qadir, 1998: 83). Hikmah di syariatkannya zakat terbagi menjadi tiga aspek yaitu aspek diniyyah, khuluqiyyah, dan ijtimaiyyah. (Fakhruddin, 2008: 30)

Zakat merupakan salah satu sumber keuangan yang penting bagi negara pada masa awal islam, karena sifatna yang sangat erat dengan kekuatan negara pada zaman Nabi. Zakat sangat berpotensi menghilangkan konsentrasi kekayaan dikalangan elot ekonomi tertentu, selain itu juga berpotensi meningkatkan produktivitas masyarakat miskin melalui pembinaan dan bantuan modal usaha. Lebih dari itu zakat ternyata memiliki fungsi yang sangat strategis dalam konteks system ekonomi. Dengan pengelolaan yang baik, zakat merupakan sumber dana potensial dan sebagai salah satu instrument penting dalam sector ekonomi islam dan mendorong kemajuan dan kemakmuran umat Islam.

Pendapatan dan pengeluaran dalam ramah ekonomi islam salah satunya diatur melalu mekanisme zakat. Pembaharuan zakat menjadi penting untuk dilakukan, karena selama ini sebagian besar umat masih memandang zakat sebagai ibadah yang terlepas kaitannya dengan persoalan ekonomi dan sosial, maka saat ini zakat harus di pandang sebagai sumber-sumber kekuatan ekonomi umat yang dapat dipergunakan untuk menyelesaikan berbagai permasalahan sosial umat islam. Dalam praktiknya zakat masih kurang menyentuh masyarakat, tidak tepat pada sasaran. Sebagai upaya wujudkan produktifitas dalam pengelolaan dana zakat,dan hasil zakat dapat dimanfaatkaan untuk meningkatkan kesejahteraan lahir batin masyarakat. Esensi dari zakat sendiri adalah selain untuk memenuhi kebutuhkan konsumtifnya juga memenuhi segala kebutuhan hidupnya termasuk pendidikan, tempat tinggal dan sandang mereka. Dari sinilah pola pemberian zakat kepada para mustahik tidak hanya bersifat konsumtif saja, namun dapat pula bersifat produktif. Pendayagunaan zakat secara produktif yang pemahamannya lebih kepada bagaimana cara atau metode menyampaikan dana zakat kepada sasaran dalam pengertian yang luas.

Pemanfaatan dana zakat produktif sesungguhnya mempunyai konsep perencanaan dan pelaksanaan yang cermat seperti mengkaji penyebab kemiskinan yang bersumber dari ketidakaan modal kerja, kekurangan lapangan kerja, tingkat pendidikan, serta kurangnya etos kerja, maka dengan adanya masalah tersebut maka perlu adanya perencanaan yang 
DOI: $1047467 /$ elmal.v1i1.313

dapat mengembangkan zakat bersifat produktif tersebut. Dengan berkembangnya usaha kecil menengah dengan modal yang berasal dari zakat akan menyerap tenaga kerja dan berkembangnya usaha para mustahik. Hal ini berarti angka pengangguran bisa berkurang, berkurangnya angka pengangguran dakan berdampak pada meningkatnya daya beli masyarakat akan diikuti oleh pertumbuhan produksi, pertumbuhan sektor produksi inilah yang akan menjadi salah satu indikator adanya pertumbuhan ekonomi

Zakat diambil dari orang-orang yang berkewajiban zakat (Muzakki) dan kemudian diberikan kepada orang yang berhak menerima zakat (Mustahiq). Zakat yang diberikan kepada mustahik akan berperan sebagia pendukung peningkatan ekonomi mereka apabila disalurkan pada kegiatan produktif, yang mengambil dan mendistribusikan zakat tersebut adalah petugas atau amil.

Pembentukan badan amil zakat merupakan wujud nyata perhatian pemerintah terhadap kehidupan umat islam, sehingga diperlukan sebuah mekanisme yang mampu mengalirkan harta kekayaan yang di miliki oleh kelompok masyarakat yang berkecukupan kepada kelompok masyarakat yang tidak berkecukupan. pemerintah juga telah membentuk undangundang no. 23 tahun 2011 tentang pengelolaan zakat. Undang-undang ini memuat tentang pengelolaan zakat yang terorganisir dengan baik, transparan dan terorganisir dengan baik, transparan dan profesional dilakukan oleh amil resmi yang ditunjuk oleh pemerintah, baik Lembaga Amil Zakat (LAZ) maupun Badan Amil Zakat Nasional (BAZNAS). Zakat yang telah dikumpulkan oleh lembaga pengelola zakat harus segera disalurkan kepada para mustahik sesuai dengan skala prioritas yang telah ditentukan. (Dididn Hafidhuddin, 2002: 133)

Sekarang-sekarang ini mulai tumbuh lembaga-lembaga amil zakat yang memberikan dananya secara produktif, diantaranya adalah yang dilakukan oleh KH. Salah Mafudh, dengan membentuk Badan Pengembangan Masyarakat Pesantren (BPMP) yang memberikan dana zakat kepada kepada kaum kafir miskin dengan pendekatan kebutuhan dasar. Misalnya jika seorang Mustahiq mempunyai ketrampilan menjahit, maka ia diberi mesin jahit, kalau mempunyai keterampilan mengemudi becak ia diberi becak, agar mereka mau berusaha dan tidak menggantungkan uluran tangan orang kaya. Selain itu KH. Salah Mafudh juga melembagakan dana zakat dalam koperasi. Dana zakat yang terkumpul tidak langsung diberikan 
DOI: $1047467 /$ elmal.v1i1.313

dalam bentuk uang. Mustahiq diserahi zakat berupa uang tetapi kemudian ditarik kembali sebgaia tabungan si miskin untuk keperluan pengumpulan modal. Dengan cara ini fakir miskin bisa menciptakan pekerjaan dengan modal yang dikumpulkan dari harta zakat. (Mahfud, 2004: 119-122)

Begitu pula Dompet Dhuafa Republika sebagai salah satu lembaga zakat non pemerintah, sejak bulan Desember 1999 telah mengagendakan pengembangan pemberdayaan zakat model kelompok dengan program Masyarakat Mandiri (MM), yang telah dilaksanakan pada awal tahun 2000. Sasarannya adalah kaum fakir miskin dan dhuafa yang di fokuskan di wilayah Bogor, Tangerang dan Bekasi, Bengkulu, Tasikmalaya, Palu/poso dan Banggai Kepulauan provinsi Sulawesi Tengah. Sebgai dana Zakat Infak Sedekah (ZIS) yang terkumpul diproduktifkan dengan meminjamkannya kepada sasaran MM untuk dijadikan modal usaha dan pengembangan usaha bagi mereka. Juga Badan Zakat Infak Sedekah (BAZIS) DKI Jakarta, yang membatasi model penyaluran dana zakat secara produktif. Hal ini tertuang dalam mekanisme penyaluran dana zakat harus bersifat eduktif, produktif dan ekonomis, sehingga akhirnya penerima zakat menjadi tidak memerlukan zakat lagi, bahkan menjadi muzakki (Mahfudh, 2004:81)

Lembaga amil zakat memiliki system distribusi zakat yang di jalankan agar dana zakat yang sudah di kumpulkan tersalurkan dengan baik dan tepat sasaran. System distribusi zakat menjadi hal yang sangat penting untuk di perhatikan mengingat dalam system distribusi zakat dapat membantu pemerintah dalam meminimalisir kemiskinan yang terjadi di Indonesia.

Distribusi dana zakat merupakan salah satu kegiatan yang berhubungan langsung dengan orang-orang yang kekurangan dalam hal finansial. Oleh karena itu, distribusi mempunyai peranan yang sangat besar. Setiap lembaga tidak bisa lepas dari masalah penyaluran atau distribusi dana zakat yang diterima untuk disalurkan kepada masyarakat. Lembaga penerima dana zakat mempunyai hak untuk menentukan kebijakan distribusi.

Dalam aspek pendistribusian dana zakat, sejauh ini terdapat dua pola penyaluran dana zakat, yaitu pola tradisonal (Konsumtif) dan pola penyaluran produktif (Pemberdayaan ekenomi). Selama ini dalam prakteknya, zakat yang disalurkan kepada masyarakat lebih didominasi oleh zakat konsumtif sehingga ketika zakat tersebut selesai didistribusikan maka manfaat yang diterima oleh mustahik hanya dapat dipergunakan 
DOI: $1047467 /$ elmal.v1i1.313

dalam kurun waktu yang singkat. Tujuan zakat tidak hanya sekedar menyantuni orang miskin secara konsumtif, tetapi mempunyai tujuan yang lebih permanen yaitu mengentaskan kemiskinan dan mengubah keadaan penerima dari kategori mustahiq menjadi muzakki. (Qadir, 1998: 83)

Zakat hendaknya tidak sekedar konsumtif, maka idealnya zakat dijadikan sumber dana umat. Penggunaan zakat suntuk konsumtif hanyalah untuk hal-hal yang bersifat darurat. Artinya, ketika ada mustahik yang tidak mungkin dibimbing untuk mempunyai usaha mandiri atau memang untuk kepentingan mendesak, maka penggunaan konsumtif dapat dilakukan. (Azizy, 2004: 148-149)

Untuk itu dalam pendistribusian zakat sangat diperlukan peran kerja sama banyak pihak dan partisipasi masyarakat, di dalamnya terkandung fungsi motivasi, pembinaan, pengumpulan, perencanaan, pengawasan, dan pendistribusian. Jika semua pihak yang berwenang ikut andil untuk mensukseskan pengelolaan zakat yang yang baik dan optimal maka program pengentasan kemiskinan bukanlah mimpi. Penuntasan kemiskinan melalui zakat juga memiliki arti mengurangi mustahik dan menghasilkan muzakki yang baru. Oleh karena itu pendistribusian zakat konsumtif harus ditinjau ulang kembali dan digantikan dengan pendistribusian zakat produktif. Zakat produktif adalah pemberian zakat yang dapat membuat para penerimanya menghasilkan sesuatu secara terus menerus, dengan harta zakat yang diterimanya. (Isnaini, 2008 : 64)

Salah satu lembaga yang telah melakukan pengelolaan dan pendayagunaan dana zakat produktif yaitu Lembaga Amil Zakat (LAZ) Dompet Peduli Umat Daarut Tauhid (DPU DT) melalui Program Ikhtiar KU Zakat Produktif apabila dikelola secara optimal dapat meningkatkan kesejahteraan mustahik dengan memberikan bantuan modal usaha untuk keberlangsungan usaha yang dirintihnya.

\section{Gambar 1 Alur Distribusi Dana ZakatProduktif DT Peduli Bogor}

\begin{tabular}{|l|c|c|c|}
\hline $\begin{array}{c}\text { MUZAKKI } \\
\text { (memberikan zakat } \\
\text { yang bersumber dari } \\
\text { zakat harta, zakat } \\
\text { hewan } \\
\text { ternak,kebun,dll } \\
\text { melalui transfer } \\
\text { rekeningatau datang } \\
\text { langsung) }\end{array}$ & pmor $\mathbf{1} \mathbf{2 0 1 9}$ & $\begin{array}{c}\text { Dt Peduli Bogor } \\
\text { (mengelola dana } \\
\text { ZISWAF yang } \\
\text { diberikan serta } \\
\text { mendistribusikan nya } \\
\text { melalui 2 jalur yaitu } \\
\text { jalur konsumtif dan } \\
\text { jalur produktif. }\end{array}$ \\
menerima dana \\
ZISWAF yang sudah \\
dikelola dan \\
disalurkan oleh \\
BAZNAS SU sesuai \\
dengan kesepakatan \\
yang diberikan
\end{tabular}




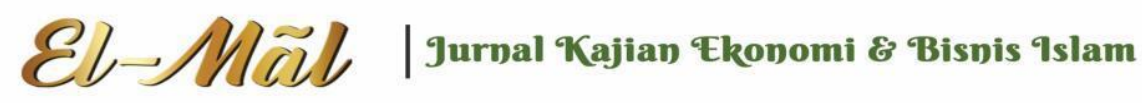

Vol 2 No 1 (2019) 18-42 P-ISSN 2620-295 E-ISSN 2747-0490

DOI: $1047467 /$ elmal.v1i1.313

\section{Penelitian Terdahulu}

Penelitian skripsi mengenai "Pengaruh Pemanfaatan Dana Zakat Produktif terhadap Tingkat Pendapatan Mustahik di Pos Keadilan Peduli Ummat Yogyakarta" yang dilakukan oleh Hafidoh pada tahun 2015. Berdasarkan hasil analisis statistik melalui paired sample t-test menunjukkan bahwa terdapat perbedaan tingkat pendapatan mustahik sebelum dan sesudah menerima zakat produktif, dimana perbedaan tersebut rata-rata mengalami peningkatan walaupun dalam jumlah yang relatif sedikit.

Penelitian Skripsi yang berjudul "Pengaruh Pembiayaan Qardhul Hasan terhadap Pendapatan Mitra Penyandang Disabilitas P.T. Karya Masyarakat Mandiri di Bekasi" oleh Jaitun Puspita Saripada tahun 2015, Berdasarkan Hasil penelitiannya maka didapat bahwa Pembiayaan Qardhu Hasan berpengaruh positif terhadap pendapatan mitra penyandang disabilitas P.T. Karya Masyarakat Mandiri, dibuktikan dengan Uji F-Test (Simultan).

Penulis tertarik meneliti pada Lembaga Amil Zakat di Dompet Peduli Umat Daarut Tauhid Cabang Bogor, dimana DPU DT Cabang Bogor mengalokasikan sebagian dana zakat untuk kegiatan produktif. Hal ini tentu membutuhkan pengelolaan, pendistribusian dan pendayagunaan dana zakat itu menjadi dana zakat produktif untuk bantuan modal usaha dalam rangka pemberdayaan para mustahiknya. Maka dari itu apakah dengan adanya program pendayagunaan dana zakat produktif yang dikelola DPU DT Cabang Bogor dapat berdaya guna dan tepat guna mempengaruhi pemberdayaan ekonomi para mustahik. Sehubungan hal tersebut maka saya sebagai peneliti tertarik untuk mengadakan penelitian dengan Judul: "Pengaruh Pendistribusian Dana Zakat Produktif Terhadap Tingkat Pendapatan Mustahik (Studi Kasus di DPU DT Cabang Bogor)“

Penelitian ini bertujuan: untuk menganalisisi mekanisme pendistribusian dana zakat yang dilakukan oleh DPU-DT dan menganalisis pendapatan 
DOI: $1047467 /$ elmal.v1i1.313

mustahik zakat setelah mendapatkan dana zakat produktif dari DPU-DT Bogor.

\section{METODE PENELITIAN}

Penelitian ini merupakan penelitian dengan metode penelitian kuantitatif yakni penelitian yang dilakukan dengan melakukan survey langsung ke obyek penelitian, survey ini dilakukan melalui kuesioner yang diajukan langsung kepada responden. Penelitian ini diawali dengan mengumpulkan data bersifat kuantitatif yang berwujud angka-angka kemudian disusun secara sistematis dan di olah dengan program Statistic Product and Service Solutiob (SPSS). Setelah diketahui hasilnya kemudian ditafsirkan dengan memberikan gambaran dan penjelasan mengenai pengaruh pendistribusian dana zakat produktif terhadap tingkat pendapatan mustahik.

Dalam penelitian ini penulis menggunakan seluruh sampel sebesar 50\% dari Jumlah 40 Mustahik yaitu 20 Mustahik. Maka jumlah ini di jadikan sebagai sampel dan obyek untuk di teliti

\section{Gambar 3.1 Teknik Simple Random Sampling}

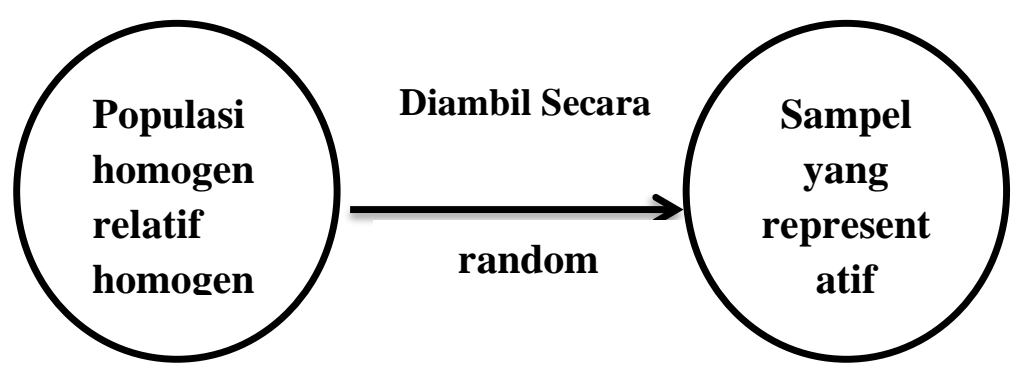

\section{Teknik Pengumpulan Data}

Adapun teknik pengumpulan data yang dilakukan dalam penelitian ini adalah sebagai berikut:

\section{1) Observasi}

25 | Vomule 2 Nomor 12019 
DOI: $1047467 /$ elmal.v1i1.313

Observasi adalah cara pengumpulan data dengan melakukan pengamatan dan pencatatan secara cermat dan sistematis terhadap fenomena yang diteliti, guna memperoleh informasi sebagai pendukung data.

\section{2) Wawancara}

Wawancara adalah cara pengumpulan data dengan mengajukan pertanyaan pertanyaan langsung kepada pihak terkait dengan topik pembahasan. Selain dengan cara observasi, penulis juga melakukan wawancara secara langsung, penulis melakukan bentuk wawancara tidak terstruktur. Adapun pihakpihak yang akan menjadi narasumber sebagai berikut:

a) Pimpinan DPU DT Bogor

b) Divisi Program DPU DT Bogor

\section{3) Kuesioner (Angket)}

Kuesioner merupakan metode pengumpulan data dengan membuat daftar pertanyaan dalam bentuk angket yang diajukan kepada mustahik yang menerima manfaat dana produktif dari DT PEDULI Bogor menggunakan Skala Likert dengan bentuk Checklist.

\section{4) Dokumen}

Metode ini digunakan untuk memperoleh data tentang dokumen, catatan atau arsip yang dimiliki perusahaan yang ada hubungannya dengan peneliti seperti struktur organisasi dan sejarah perusahaan

\section{5) Studi Kepustakaan}

Studi kepustakaan dibuat untuk mengumpulkan data dan informasi dengan bantuan bermacam-macam buku yang memberikan landasan bagi perumusan hipotesis, penyusunan kuesioner, pembahasan teoritis

\section{Instrumen Penelitian}

Instrumen penelitian digunakan untuk mengukur nilai variable yang diteliti. Dengan demikian jumlah instrument yang akan digunakan untuk penelitian akan tergantung pada jumlah variabel yang diteliti. Karena instrument penelitian akan digunakan untuk melakukan pengukuran dengan tujuan menghasilkan data kuantitatif yang akurat, maka setiap instrument harus mempunyai skala. 
Vol 2 No 1 (2019) 18-42 P-ISSN 2620-295 E-ISSN 2747-0490

DOI: $1047467 /$ elmal.v1i1.313

Tabel 3.1 Skala Likert Bentuk Checklist

\begin{tabular}{|c|c|c|c|c|c|c|}
\hline \multirow[t]{2}{*}{ No } & \multirow[t]{2}{*}{ Pertanyaan } & \multicolumn{5}{|c|}{ Jawaban } \\
\hline & & SS & ST & $\mathbf{N}$ & TS & STS \\
\hline 1. & $\begin{array}{l}\text { Pengajuan Persyaratan } \\
\text { Pembiayaan mudah dipahami }\end{array}$ & $\sqrt{ }$ & & & & \\
\hline 2. & (2) & & & & & \\
\hline
\end{tabular}

Tabel 3.2 Skor dari tiap pertanyaan

\begin{tabular}{|l|c|}
\hline \multicolumn{1}{|c|}{ Pertanyaan ( Pilihan) } & Skor \\
\hline (SS) = Sangat Setuju & 5 \\
\hline (ST) = Setuju & 4 \\
\hline (N) = Netral & 3 \\
\hline (TS) = Tidak Setuju & 2 \\
\hline (STS) = Sangat Tidak Setuju & 1 \\
\hline
\end{tabular}

\section{Lokasi dan Waktu Penelitian}

Lokasi yang dipilih sebagai tempat penelitian adalah kantor DT Peduli Bogor, yang bealamat di Ruko Johar Grande No.3 jl. Johar Raya Taman Cimanggu, Kec. Tanah Sareal Kota Bogor. Rt 02/ Rw 04 Kel. Kedung Waringin Kota Bogor Jawa Barat 16161. Rencana Penelitian dimulai dari Mei - Juli 2020

\section{HASIL PENELITIAN DAN PEMBAHASAN}

DPU DT didirikan pada 16 Juni 1999 oleh KH. Abdullah Gymnastiar (Aa Gym) sebagai bagian dari Yayasan Daarut Tauhiid dengan tekad menjaga LAZ yang amanah, professional dan akuntabilitas Latar belakang berdirinya DPU DT adalah melihat Indonesia sebagai Negara dengan jumlah penduduk muslim terbesar di dunia memiliki potensi zakat yang amat besar. Hanya saja, persentase masyarakat yang memiliki kesadaran menunaikan kewajiban zakat sesuai dengan ketentuan masih relative kecil dibanding dengan potensi zakat di Indonesia. 


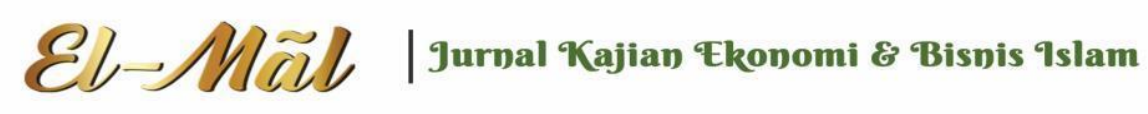

Vol 2 No 1 (2019) 18-42 P-ISSN 2620-295 E-ISSN 2747-0490

DOI: $1047467 /$ elmal.v1i1.313

DPU DT secara efektif menjalankan aktivitasnya pada tanggal 16 Juni 2000 dengan berbasiskan database, dimana setiap donator mempunyai nomor dan kartu anggota sehingga kepedulian dan komitmen donator dapat erukur. Dari aspek legal formal, DPU DT dilakukan sebagai Lembaga Amil Zakat Daerah Jawa Bara oleh Gubernur Jawa Barat pada tanggal 19 Agustus 2002, dengan SK No. 451.12/Kep.846-YANSOS/2002 Kiprah DPU DT pun mendapat perhatian pemerintah pusat dalam waktu yang cukup singkat sejak masa berdiri DPU DT dan menjadi LAZDA, sudah berhasil menjadi Lembaga Amil Zakat Nasional (LAZNAS) sesuai dengan SK Menteri Agama No. 410 tahun 2004 pada tanggal 13 Oktober 2004.

Mulai tahun 2004, DPU Daarut Tauhiid mengembangkan Konsep penyaluran dana zakat bergulir berkesinambungan, untuk para peerima zakat agar suatu saat dapat meningkatkan taraf hidupnya dan mampu berubah dari penerima zakat menjadi pemberi zakat, lembag tidak hanya memeberikannya saja, melainkan juga membekalinya, agar mereka bisa terus berusaha dan meingkatkan taraf hidupnya. Oleh karena itu, saat ini peningkatan kekuatan ekonomi dan pembelajaran bagi masyarakat merupakan prioritas yang harus di utamakan, sehingga upaya-upaya untuk menumbuhkan kemampuan dan kemandirian ummat yang berasal dari sinergi potensi masyarakat patut untuk diwujudkan secara Bersama-sama. (DPUDT, 2017)

\section{Temuan Penelitian}

Temuan Penelitian ini untuk mengetahui apakah Pendistribusian dana zakat produktif berpengaruh terhadap tingkat pendapatan Mustahik DPU DT Bogor. Data di peroleh melalui penyebaran kuesioner atau angket dan di olah dengan menggunakan bantuan Program SPSS Versi 26.0

\section{Profil Responden}

Berdasarkan standar kesejahteraan menurut Badan Pusat Statistik (BPS), beberapa indikator yang menjadi tolak ukur kesejahteraan masyarakat yaitu antara lain pendapatan, pengeluaran, tempat tinggal, fasilitas tempat tinggal, kesehatan, kemudahan mendapat pelayanan kesehatan, pendidikan dan transport. 8 indikator ini menjadi penting untuk dibahas mengenai perkembangannya antara sebelum dan sesudah Mustahik menerima dana bantuan modal usaha dalam bentuk zakat produktif (GEROBAK BERKAH).

28 | Vomule 2 Nomor 12019 
DOI: $1047467 /$ elmal.v1i1.313

Berdasarkan jenis kelamin, respon penerima dana zakat adalah 11 orang (55\%) perempuan dan 9 orang (45\%) laki-laki. Mereka mayoritas berusia 2020 tahun (55\%), dan 45\% berusia 40-50 tahun. Adapun berdasarkan pendidikan terakhirnya, profil responden penerima dana zakat produktif sebagai berikut:

Tabel Klasifikasi Responden Berdasarkan Pendidikan

\begin{tabular}{|l|l|l|}
\hline Pendidikan Terakhir & Jumlah & Presentase $\%$ \\
\hline Tidak Tamat SD & 4 & $20 \%$ \\
\hline SD & 7 & $35 \%$ \\
\hline SMP & 5 & $25 \%$ \\
\hline SMA & 4 & $40 \%$ \\
\hline Total & 20 & $100 \%$ \\
\hline
\end{tabular}

Sumber : Data di olah Peneliti

Berdasarkan tingkat pendapatannya, responden penerima dana zakat produktif sebagai berikut:

Tabel Pendapatan Responden Sebelum Mendapat Dana Zakat Produktif

\begin{tabular}{|l|l|l|}
\hline Pendapatan Mustahik & Jumlah & Presentase $\%$ \\
\hline <Rp. 500.000 & 11 & $55 \%$ \\
\hline Rp. $500.000-$ Rp. 1.000 .000 & 8 & $40 \%$ \\
\hline Rp. $1.000 .000-$ Rp. 2.000 .000 & 1 & $5 \%$ \\
\hline Rp. $2.000 .000-$ Rp. 3.000 .000 & 0 & $0 \%$ \\
\hline$>$ Rp.3.000.000 & 0 & $0 \%$ \\
\hline Total & 20 & $100 \%$ \\
\hline
\end{tabular}

Sumber : Data diolah

Adapun berdasarkan pendapatan setelah mendapat dana produktif, profil responden adalah sebagai berikut :

Tabel Pendapatan Responden Setelah Mendapat Dana Zakat Produktif

\begin{tabular}{|l|l|l|}
\hline Pendapatan Mustahik & Jumlah & Presentase \% \\
\hline$<$ Rp. 500.000 & 5 & $25 \%$ \\
\hline
\end{tabular}

29 | Vomule 2 Nomor 12019 
Vol 2 No 1 (2019) 18-42 P-ISSN 2620-295 E-ISSN 2747-0490

DOI: 1047467/elmal.v1i1.313

\begin{tabular}{|l|l|l|}
\hline Rp. $500.000-$ Rp. 1.000 .000 & 13 & $65 \%$ \\
\hline Rp. $1.000 .000-$ Rp. 2.000 .000 & 2 & $10 \%$ \\
\hline Rp. $2.000 .000-$ Rp. 3.000 .000 & 0 & $0 \%$ \\
\hline >Rp.3.000.000 & 0 & $0 \%$ \\
\hline Total & 20 & $100 \%$ \\
\hline
\end{tabular}

Sumber : Data di olah oleh peneliti

\section{Hasil Penelitian}

\section{Uji Validitas}

Uji Validitas digunakan untuk mengukur apakah valid atau sahnya pertanyan suatu kuesioner. Kuesioner danggap valid apabila pertanyaan tersebut dapat mengungkapkan sesuatu yang diukur dari kuesioner. Uji validitas pada penelitian ini menggunakan SPSS Version 26.0.

Suatu butir angket dinyatakan valid apabila $r_{\text {hitung }}>r_{\text {tabel. Nilai }}$ $r_{\text {tabel }}$ untuk uji dua arah pada taraf kepercayaan 95\%atau signifikasi $5 \%(\mathrm{p}=0,05)$ dapat dicari berdasarkan jumlah responden atau $\mathrm{N}$. Oleh karena $\mathrm{N}=20$, maka derajat bebasnya adalah $\mathrm{N}-2=20-2=18$. Nilai $r_{\text {tabel }}$ dua arah pada $\mathrm{df}=20$ dan $\mathrm{p}=0,05$ adalah 0,4438 . Hasil output SPSS yang diperoleh

untuk uji validitas dari variabel Pendistribusian Dana Zakat Produktif (X) dan Tingkat pendapatan mustahik (Y) DPU DT Kota Bogor dapat dilihat di bawah ini :

Tabel 4.8 Hasil Uji Validitas Pendistribusian Dana Zakat Produktif (X)

\begin{tabular}{|l|l|l|l|}
\hline No Butir & $r_{\text {hitung }}$ & $r_{\text {tabel }}$ & Satuan \\
\hline 1 & 0,730 & 0,4438 & Valid \\
\hline 2 & 0,456 & 0,4438 & Valid \\
\hline 3 & 0,814 & 0,4438 & Valid \\
\hline 4 & 0,0539 & 0,4438 & Valid \\
\hline 5 & 0,664 & 0,4438 & Valid \\
\hline 6 & 0,722 & 0,4438 & Valid \\
\hline 7 & 0,841 & 0,4438 & Valid \\
\hline 8 & 0,620 & 0,4438 & Valid \\
\hline
\end{tabular}

Sumber : Data di Olah oleh Peneliti 
DOI: $1047467 /$ elmal.v1i1.313

Berdasarkan hasil analisis tersebut, maka dapat disimpulkan semua butir angket yang digunakan dalam variabel Pendistribusian Dana Zakat Produktif (X) DPU DT Kota Bogor dinyatakan Valid.

Tabel 4.9 Hasil Uji Validitas Tingkat Pendapatan Mustahik (Y)

\begin{tabular}{|l|l|l|l|}
\hline No Butir & $r_{\text {hitung }}$ & $r_{\text {tabel }}$ & Satuan \\
\hline 1 & 0,657 & 0,4438 & Valid \\
\hline 2 & 0,677 & 0,4438 & Valid \\
\hline 3 & 0,702 & 0,4438 & Valid \\
\hline 4 & 0,804 & 0,4438 & Valid \\
\hline 5 & 0,767 & 0,4438 & Valid \\
\hline 6 & 0,840 & 0,4438 & Valid \\
\hline 7 & 0,680 & 0,4438 & Valid \\
\hline 8 & 0,840 & 0,4438 & Valid \\
\hline
\end{tabular}

Sumber : Data di Olah oleh Peneliti

Berdasarkan hasil analisis tersebut, maka dapat disimpulkan semua butir angket yang digunakan dalam variabel Tingkat Pendapatan Mustahik (Y) DPU DT Kota Bogor dinyatakan Valid.

\section{Uji Reliabilitas}

Uji Realibilitas digunakan untuk melihat kestabilan dan konsistensi dari responden dalam menjawab hal yang berkaitan dengan pertanyaan yang disusun dalam suatu bentuk angket. Hasil uji ini akan mencerminkan dapat atau tidaknya suatu instrumen penelitian dipercaya, berdasarkan tingkat ketepatan dan kemantapan suatu alat ukur.

Standar yang digunakan dalam menentukan reliabel atau tidak reliabelnya suatu instrumen penelitian, salah satunya dengan melihat perbandingan antara nilai $r_{\text {hitung }}$ dengan $r_{\text {tabel }}$ pada taraf kepercayaan 95\% (signifikansi 5\%). Jika pengujian dilakukan dengan metode Alpha Cronbach maka rhitung akan diwakili oleh nilai Alpha. Suatu angket atau kuesioner dapat dikatakan handal (reliabel) apabila memiliki kehandalan atau alpha sebesar 0,6 atau lebih. Nilai Alpha yang semakin mendekati 1 menunjukkan semakin tinggi konsistensi internal reliabilitasnya. 
Vol 2 No 1 (2019) 18-42 P-ISSN 2620-295 E-ISSN 2747-0490

DOI: $1047467 /$ elmal.v1i1.313

Adapun tingkat reliabilitas variabel Pendistribusian Dana Zakat Produktif (X) dan variabel Tingkat pendapatan mustahik (Y) berdasarkan hasil olahan SPSS Version 26.0 dapat dilihat pada tabel di bawah ini :

Tabel 4.10 Uji Reliabilitas Pendistribusian Dana Zakat Produktif (X)

\begin{tabular}{|r|r|}
\hline \multicolumn{2}{|c|}{ Reliability Statistics } \\
\hline Cronbach's Alpha & N of Items \\
\hline, 815 & \\
\hline
\end{tabular}

Dari Hasil Uji Realibilitas diatas di peroleh nilai Cronbach's Alpha sebesar 0,815 dengan jumlah pertanyaan 8 item. Nilai $r_{\text {tabel }}$ pada taraf kepercayaan 95\% (Signifikansi 5\%) dengan jumlah responden $\mathrm{N}=20$ dan $\mathrm{df}=\mathrm{N}-2=20-2=18$ adalah 0,4438 . Dengan demikian, nilai alpha cronbach's 0,815 >0,4438. Sehingga dapat disimpulkan bahwa angket reliabel. Realibilitas ini juga ditunjukka dengan nilai alpha cronbach's sebesar $>0,60$ sehingga dapat di simpulkan alat ukur penelitian ini reliael (handal)

Tabel 4.11 Uji Reliabilitas Tingkat Pendapata Mustahik (Y)

\begin{tabular}{|r|r|}
\hline Cronbach's Alpha & N of Items \\
\hline, 885 & \\
\hline
\end{tabular}

Dari Hasil Uji Realibilitas diatas di eroleh nilai Cronbach's Alpha sebesar 0,885 dengan jumlah pertanyaan 8 item. Nilai rtabel pada taraf keprcayaan 95\% (Signifikansi 5\%) dengan jumlah responden $\mathrm{N}=20$ dan $\mathrm{df}=\mathrm{N}-2=20-2=18$ adalah 0,4438 . Dengan demikian, nilai alpha cronbach's $0,885>0,4438$. Sehingga dapat disimpulkan bahwa angket reliabel. Realibilitas ini juga ditunjukkan dengan nilai alpha cronbach's sebesar $>0,60$ sehingga dapat di simpulkan alat ukur penelitian ini reliael (handal)

\section{Uji Normalitas}

\subsubsection{Uji Normalitas Kolmogorov - Smirnov Test}

Uji Normalitas digunakan untuk melihat hasil sebaran data kuesioner apakah berdistribusi normal atau tidak. Uji 
DOI: $1047467 /$ elmal.v1i1.313

normalitas data dilakukan dengan menggunakan metode uji Kolmogorov - Smirnov. Penerapan pada uji Kolmogorov smirnov adalah bahwa jika signifikan atau nilai probalitas dengan data normal baku, berarti data tersebut tidak normal. Namun jika signifikansi diatas 0,05 maka berarti tidak terdapat perbedaan yang signifikan antara data yang akan diujikan dengan data normal baku , artinya data yang kita uji normal.

Table 4.12 Uji Normalitas One-Sample KolmogorovSmirnov test

\begin{tabular}{|c|c|c|}
\hline \multicolumn{3}{|c|}{ One-Sample Kolmogorov-Smirnov Test } \\
\hline & & Unstandardized Residual \\
\hline \multicolumn{2}{|l|}{$\mathrm{N}$} & 20 \\
\hline \multirow{2}{*}{$\begin{array}{l}\text { Normal } \\
\text { Parameter } \\
\mathrm{s}^{\mathrm{a}, \mathrm{b}}\end{array}$} & Mean & 0000000 \\
\hline & Std. Deviation & 3,09062910 \\
\hline \multirow{3}{*}{$\begin{array}{l}\text { Most } \\
\text { Extreme } \\
\text { Difference } \\
\text { s }\end{array}$} & Absolute & ,116 \\
\hline & Positive & 066 \\
\hline & Negative &,- 116 \\
\hline \multicolumn{2}{|c|}{ Test Statistic } & ,116 \\
\hline \multicolumn{2}{|c|}{ Asymp. Sig. (2-tailed) } & $200^{c, d}$ \\
\hline
\end{tabular}

a. Test distribution is Normal.

b. Calculated from data.

c. Lilliefors Significance Correction.

$\mathrm{d}$. This is a lower bound of the true significance.

Berdasarkan output diatas, diketahui bahwa nilai signiikansinya terlihat pada kolom Asymp. Sig. (2-tailed) sebesar 0,200 dan lebih besar dari 0,05, Unstandardized Residual 0,200 > 0,05. Maka dapat disimpulkan bahwa data yang diuji berdistribusi dengan normal melalui SPSS Version 26.0

\section{Uji Heteroskedastistas}

Uji Heteroskedastistas digunakan utuk mengetahui ada atau tidaknya penyimpangan. Sebuah model regresi yang 
DOI: $1047467 /$ elmal.v1i1.313

baik adalah yang tidak memiliki heteroskedastisitas. Sementara itu, terjadinya gejala atau masalah heteroskedatisitas ini akan berakibat pada sebuah keraguan (ketidak akuratan) pada suatu hasil analisis regresi yang di lakukan.

\section{Hasil Uji Heteroskedastisitas (Scatterplot) SPSS Versi 26.0}

Gambar 4.3

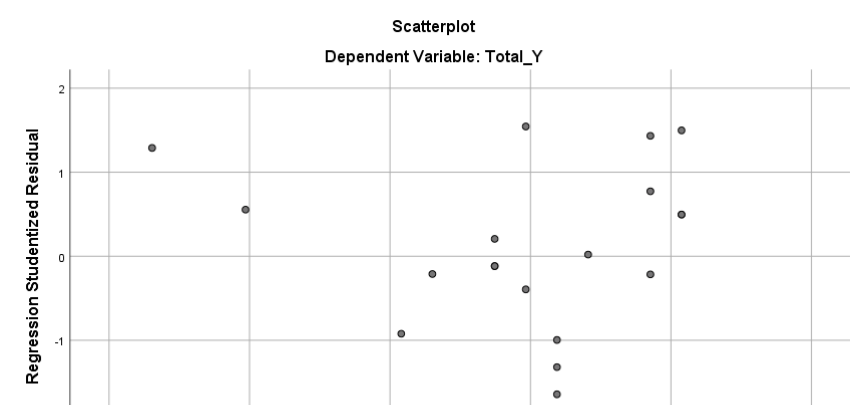

Dari gambar diatas dapat dilihat båhwa titik-titik pada scatterplot menyebar seemen mematak pola tertentu. Jika tidak ada pola yang jelas, serta titik-titik menyebar di atas dan bawah 0 pada sumbu y, maka tidak terjadi heteroskedastisitas.

\section{Uji Koefesien Determinasi (R2)}

Uji Koefisien determinasi digunakan untuk mengetahui seberapa besar pengaruh Variabel Pendistribusian Dana Zakat Produktif (X) terhadap tingkat Pendapatan Mustahik (Y). berikut ini adalah hasil yang menggambarkan nilai koefisien determinasi.

Jika nilai koefisien determinan berkisar antara nol maka hubungan antara kedua variabel dinyatakan lemah. Jika angka mendekati satu maka dinyatakan sangat kuat

Tabel 4.13 Hasil Uji Koefisien Determinasi

\begin{tabular}{|l|l|r|r|r|}
\hline \multicolumn{5}{|c|}{ Model Summaryb } \\
\hline Model & R & R Square & $\begin{array}{c}\text { Adjusted R } \\
\text { Square }\end{array}$ & $\begin{array}{r}\text { Std. Error of } \\
\text { the Estimate }\end{array}$ \\
\hline 1 &, $782^{\mathrm{a}}$ &, 611 &, 589 & 3,175 \\
\hline
\end{tabular}


Vol 2 No 1 (2019) 18-42 P-ISSN 2620-295 E-ISSN 2747-0490

DOI: $1047467 /$ elmal.v1i1.313

a. Predictors: (Constant), Pendistribusian dana Zakat

Produktif

b. Dependent Variable: Tingkat Pendapatan Mustahik

Berdasarkan tabel diatas, diperoleh nilai korelasi atau hubungan (R) yaitu sebesar 0,782 dan besarnya persentasi pengaruh variabel-variabel bebas atau Pendistribusian Dana Zakat produktif dengan variabel terikat atau tingkat pendapatan mustahik yang disebut koefisien determinasi ( $\mathrm{R}$ Square) sebesar 0,611 atau $61,1 \%$. artinya pengaruh Pendistribusian Dana Zakat Produktif terhadap tingkat pendapatan Mustahik adalah sebesar 61,1\% , sedangkan sisanya sebesar 38,9\% dipengaruhi oleh variable lain yang tidak dimasukan dalam penelitian ini.

\section{Uji Regresi Linear Sederhana}

Uji Regresi linear sederhana digunakan untuk menguji atau memprediksi pengaruh satu variabel bebas atau Independet terhadap variabel terikat atau dependent. Bila skor varabel bebas diketahui, maka skor variabel terikatnya dapat diprediksi besarnya.

Tabel 4.14 Variabel Entered / Removed

\begin{tabular}{|l|l|l|l|}
\hline \multicolumn{3}{|c|}{ Variables Entered/Removed $^{\mathbf{a}}$} \\
\hline Model & \multicolumn{1}{|c|}{ Variables Entered } & $\begin{array}{r}\text { Variables } \\
\text { Removed }\end{array}$ & Method \\
\hline 1 & $\begin{array}{l}\text { Pendistribusian_Dana_Zakat_P } \\
\text { roduktif }\end{array}$ & Enter \\
\hline
\end{tabular}

a. Dependent Variable: Tingakat Pendapatan Mustahik b. All requested variables entered.

Pada Tabel diatas, variable entered atau Removed menjelaskan tentang cara yang digunakan untuk analisis regresi linear sederhana adalah dengan metode Enter dengan Tingkat pendapatan Mushtahik sebagai Variabel Terikatnya. 
Vol 2 No 1 (2019) 18-42 P-ISSN 2620-295 E-ISSN 2747-0490

DOI: $1047467 /$ elmal.v1i1.313

Tabel 4.15 ANOVA

\begin{tabular}{|c|c|c|c|c|c|c|}
\hline \multicolumn{7}{|c|}{ ANOVAa } \\
\hline \multicolumn{2}{|c|}{ Model } & $\begin{array}{l}\text { Sum of } \\
\text { Squares }\end{array}$ & Df & $\begin{array}{c}\text { Mean } \\
\text { Square }\end{array}$ & $\mathrm{F}$ & Sig. \\
\hline \multirow[t]{3}{*}{1} & $\begin{array}{l}\text { Regressio } \\
\mathrm{n}\end{array}$ & 285,062 & 1 & 285,062 & 28,273 &, $000^{\mathrm{b}}$ \\
\hline & Residual & 181,488 & 18 & 10,083 & & \\
\hline & Total & 466,550 & 19 & & & \\
\hline \multicolumn{7}{|c|}{ a. Dependent Variable: Tingkat Pendapatan Mustahik } \\
\hline \multicolumn{7}{|c|}{$\begin{array}{l}\text { b. Predictors: (Constant), Pendistribusian Dana Zakat } \\
\text { Produktif }\end{array}$} \\
\hline
\end{tabular}

Pada Tabel ANOVA diatas, pada bagian ini menjelaskan apakah ada pengaruh yang nyata (signifikan) antara variable Pendistribusian Dana Zakat Produktif (X) terhadap Variabel Tingkat Pendapatan Mustahik (Y). Dari tabel ini terlihat bahwa $F_{\text {hitung }}=28,273>F_{\text {tabel }}=4,41$ dengan tingkat signifikansi atau probabilitas 0,000 0,05 maka model regresi dapat dipakai untuk memprediksi variabel pendapatan Mustahik. Dan dapat disimpulkan bahwa terdapat pengaruh yang nyata (signifikan) antara variabel pendistribusian dana zakat produktif $(\mathrm{X})$ terhadap variabel Tingkat Pendapatan Mustahik (Y)

Tabel 4.16 Uji Regresi Linear sederhana

\begin{tabular}{|c|c|c|c|c|c|c|}
\hline \multicolumn{7}{|c|}{ Coefficients $^{a}$} \\
\hline \multirow{2}{*}{\multicolumn{2}{|c|}{ Model }} & \multicolumn{2}{|c|}{$\begin{array}{l}\text { Unstandardi } \\
\text { zed } \\
\text { Coefficients }\end{array}$} & \multirow{2}{*}{$\begin{array}{c}\begin{array}{c}\text { Standardize } \\
\mathrm{d}\end{array} \\
\text { Coefficients } \\
\text { Beta }\end{array}$} & \multirow{3}{*}{$\frac{t}{, 315}$} & \multirow{3}{*}{$\begin{array}{l}\text { Sig. } \\
, 756\end{array}$} \\
\hline & & B & $\begin{array}{l}\text { Std. } \\
\text { Error }\end{array}$ & & & \\
\hline \multirow[t]{2}{*}{1} & $\begin{array}{l}\text { (Constan } \\
\text { t) }\end{array}$ & $\begin{array}{r}1,60 \\
0 \\
\end{array}$ & $\begin{array}{r}5,08 \\
1 \\
\end{array}$ & & & \\
\hline & Total_X & ,859 & ,162 & ,782 & $\begin{array}{r}5,31 \\
7\end{array}$ & ,000 \\
\hline
\end{tabular}


DOI: $1047467 /$ elmal.v1i1.313

a. Dependent Variable: Tingkat Pendapatan Mustahik

Berdasarkan tabel diatas, terdapat nilai koefisien arah regresi dengan melihat hasil tabel coefficients ${ }^{a}$. Pada kolom unstandardized coefficients dalam sub kolom B, terdapat nilai Constant (Konstanta) sebesar 1,600. Sedangkan nilai koefisien arah regresi 0,782. Maka diperoleh persamaan regresi dengan rumus sebagai berikut:

$$
\begin{gathered}
Y=a+b X \\
Y=1,600+0,859
\end{gathered}
$$

Persamaan di atas dapat diartikan sebagai berikut:

a) Konstanta sebesar 1,600, menyatakan bahwa jika variabel Pendistribusian Dana Zakat Produktif (X) nilainya adalah konstan, maka variabel Tingkat Pendapatan Mustahik (Y) nilainya positif sebesar 1,600

b) Koefisien regresi variabel Pendistribusian Dana Zakat Produktif (X) sebesar 0,859, menyatakan bahwa setiap kenaikan 1\% Pendistribusian Dana Zakat Produktif (X), maka variabel tingkat pendapatan Mustahik (Y) akan mengalami peningkatan sebesar 0,859. Koefisien bernilai positif artinya antara pengaruh pendistribusian dana zakat produktif dengan tingkat pendapatan mustahik. Semakin bertambahnya jumlah dana zakat yang di didtribusikan maka semakin tinggi tingkat pendapatan mustahik

\subsubsection{Uji T}

Uji T bertujuan untuk mengetahui apakah variabel bebas atau Pendistribusian Dana Zakat Produktif (X) secara parsial ataupun individual berpengaruh signifikan terhadap variabel terikat atau Tingkat pendapatan mustahik (Y). Dalam menentukan derajat bebas dapat digunakan rumah $\mathrm{df}=\mathrm{N}-\mathrm{k}$ $=20-2=18$

Untuk melihat Kembali nilat $\mathrm{t}$ dapat dilihat dari perhitungan dibawah ini : 
Vol 2 No 1 (2019) 18-42 P-ISSN 2620-295 E-ISSN 2747-0490

DOI: 1047467/elmal.v1i1.313

$$
\begin{aligned}
& t=\frac{r \sqrt{\mathrm{n}-2}}{\sqrt{1-r^{2}}} \\
& t=\frac{0,782 \sqrt{20-2}}{\sqrt{1-0,611}} \\
& t=\frac{0,782 \times 4,24264069}{\sqrt{1-0,389}} \\
& t=\frac{3,3177450173}{0,6237} \\
& t=5,317
\end{aligned}
$$

\subsubsection{Hipotesis}

Uji Hipotesis pada penelitian ini adalah uji T. Uji T digunakan untuk menguji apakah terdapat pengaruh yang signifikan anatara variable $\mathrm{X}$ dan variaebl $\mathrm{Y}$. Apabila thitung $>\mathrm{t}_{\text {tabel }}$ maka hipotesis diterima dan sebaliknya.

Diketahui $t_{\text {hitung }}=5,317$ dan $t_{\text {tabel }}=2,100$ dengan nilai signifikan 0,05 . Berdasarkan nilai tersebut, $t_{\text {hitung }}>t_{\text {tabel }}(5,317$ $>2,100$ ), maka variable bebas atau Pendistribusian Dana Zakat Produktif (X) berpengaruh terhadap tingkat pendapatan Mustahik (Y). Dan berdasarkan nilai signifikan hasil output SPSS Statistic versi 26.0 nilai signifikan 0,000 0,05 maka variable bebas atau Pendistribusian dana zakat produktif (X) berpengaruh signifikan terhadap variable terikat atau tingkat pendapatan Mustahik (Y). Dapat disimpulkan bahwa Ho ditolak dan $\mathrm{Ha}$ diterima artinya secara parsial terdapat pengaruh antara Pendistribusian Dana Zakat Produktif terhadap Tingkat pendapatan Mustahik DPU DT Bogor

\section{Hasil Pembahasan}

Dompet Peduli Ummat Daarut Tauhid (DPU DT) memiliki empat program utama salah satunya yaiu Program IkhtiarKu melalui Program Gerobak Berkah. Program ini bertujuan membantu masyarakat dan memiliki harapan ke depan bahwa program Gerobak Berkah benar-benar dapat meningkatkan perekonomian penerima manfaat. 


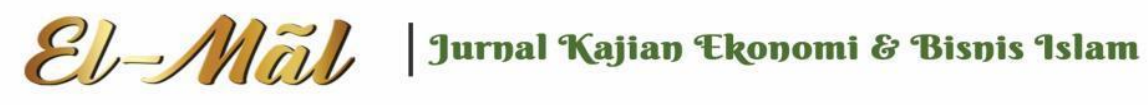

Vol 2 No 1 (2019) 18-42 P-ISSN 2620-295 E-ISSN 2747-0490

DOI: $1047467 /$ elmal.v1i1.313

Penerima manfaat ini diberikan bantuan usaha berupa Gerobak berkah yang diberikan sesuai dengan kebutuhan dan bidang usaha masing-masing mustahik, tidak ada biaya yang harus di keluarkan oleh penerima manfaat Gerobak berkah selama penyaluran hingga dimanfaatkan Gerobak berka selama usaha.

Hasil penelitian diperoleh hasil uji t (parsial) yang menunjukkan thitung $>t_{\text {tabel }}(5,317>2,100)$ dengan signifikan yaitu 0,000 . Ini artinya bahwa terdapat pengaruh antara Pendistribusian Dana Zakat Produktif terhadap Tingkat Pendapatan Mustahik. Apabila Pendistribusian dana zakat produktif ini lebih tinggi maka pendapatan Mustahik juga dapat meningkat. Berdasarkan hasil penelitian Pendistribusian dana Zakat Produktif yang diberikan oleh DT Peduli Bogor memberi pengaruh sebesar 61,1\% terhadap Tingkat Pendapatan Mustahik, sednagkan sisanta dipengaruhi oleh variable lain yang tidak dimasukkan dalam penelitian ini sebersar 38,9\% dapat diperoleh melalui Uji Koefisien determinasi digunakan untuk mengetahui seberapa besar pengaruh Variabel Pendistribusian Dana Zakat Produktif (X) terhadap tingkat Pendapatan Mustahik (Y), hasil output SPSS Version 26.0

Pendistribusian zakat produktif yang diberikan oleh DT Peduli Bogor kepada mustahik tidak membebani para mustahik. Adapun syarat-syarat yang tidak sulit. Mustahik yang menjalankan usaha namun mengalami kesulitan dalam modal usaha merasa terbantu dengan Pemberian manfaat Gerobak Berkah.

\section{KESIMPULAN DAN SARAN}

\section{Kesimpulan}

Berdasarkan Penelitian tentang Pengaruh Pendistribusian Dana Zakat Produkif Terhadap Tingkat Pendapatan Mustahik di DPU DT Bogor, melalui Program IkhtiarKu penerima Manfaat Gerobak berkah dan berbagai uraian hasil penelitian telah dijelaskan dalam bab - bab sebelumnya, maka penulis dapat disimpulkan bahwa

Program DPU DT melalui program IkhtiarKu Zakat, penerima manfaat ini diberikan bantuan usaha berupa Gerobak berkah yang diberikan sesuai dengan kebutuhan dan bidang usaha masing-masing mustahik, tidak ada biaya yang harus di keluarkan oleh penerima manfaat Gerobak berkah selama penyaluran hingga dimanfaatkan Gerobak berkah selama usaha. 


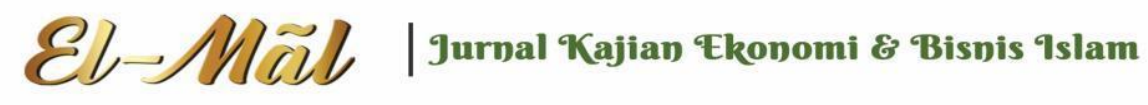

Vol 2 No 1 (2019) 18-42 P-ISSN 2620-295 E-ISSN 2747-0490

DOI: $1047467 /$ elmal.v1i1.313

Pendistribusian zakat produktif yang diberikan oleh DT Peduli Bogor kepada mustahik tidak membebani para mustahik. Adapun syarat-syarat yang tidak sulit. Mustahik yang menjalankan usaha namun mengalami kesulitan dalam modal usaha merasa terbantu dengan Pemberian manfaat Gerobak Berkah.

Pendistribusian Dana Zakat Produktif Terhadap Tingkat Pendapatan Mustahik dala program penerima manfaat Gerobak Berkah memberikan pengaruh sebesar 61,1\% terhadap tingkat pendapatan Mustahik, sedagkan sisanta dipengaruhi oleh faktor-faktor lain yang tidak dimasukkan kedala penelitian ini sebesar 38,9\%. Secara hasil uji t atau parsial, Pendistribusian Dana Zakat Produktif berpengaruh positif signifikan terhadap Tingkat Pendapatan Mustahik. Nilai thitung $>t_{\text {tabel }}(5,317>2,100)$, yang berarti hipotesis Ho ditolak dan Ha diterima bahwa Pendistribusian Dana Zakat Produktif berpengaruh terhadap Tingkat Pendapatan Mustahik.

\section{Saran}

Berdasarkan hasi penelitian yang peniliti lakukan, maka dapat diajukan beberapa saran sebagai berikut :

1) Disarankan kepada pihak DPU DT Cabang Bogor / DT Peduli Bogor untuk terus meningkatkan kinerja atas program-program yang telah ada, salah satunya dalam hal program pemanfaatan Dana Zakat Produktif melalui program IkhtiarKu yang bertujuan membantu masyarakat dan dapat meningkatkan perekonomian masyarakat, jumlah Dana zakat yang di distribusikan bisa lebih ditambah lagi, bukan hanya di beri dalam bentuk gerobaknya saja, melainkan diberikan penambahan Modal awal untuk membuka usaha

2) Dalam hal pengawasan dari pihak DPU DT harus continue dalam melakukan pengawasan terhadap kegiatan Mustahik penerima manfaat, sehingga tidak ada yang menyalah gunakan pemberian manfaat Gerobak Berkah Tersebut

3) Untuk penelitian selanjutnya sebaiknya dapat menambah variabelvariabel penelitian yang belum dicantumkan dalam penelitian ini, sehingga DPU DT Bogor ini semakin banyak membantu perekonomian masyarakat saat ini 


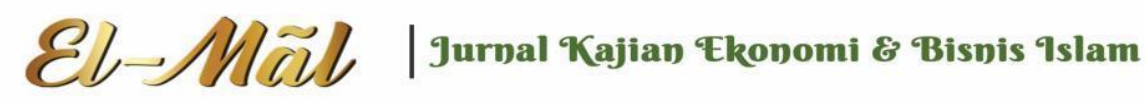

Vol 2 No 1 (2019) 18-42 P-ISSN 2620-295 E-ISSN 2747-0490

DOI: $1047467 /$ elmal.v1i1.313

\section{DAFTAR PUSTAKA}

Al-Qur'an dan Terjemah, 2012. kementrian Agama RI. Bandung: Syaamil Qur'an, Cetakan Pertama Andri Seomitra, 2009. Bank dan Lembaga Keuangan Syariah, Jakarta: Kencana Asnaini, 2008. Zakat Prdoduktif dalam perspektif Hukum Islam. Yogyakarta : Pustaka Pelajar

Dedikbud, 2005. Kamus Besar Bahasa Indonesia. Jakarta: Balai Pustaka Dr. H. Sai Fuddin Zuhri, 2012. Zakat Di era Reformasi (Tata Kelola Baru) UU Pengelolaan Zakat no. 232011

Fakhruddin, 2008. Fiqh Dan Manajemen Zakat di Indonesia. Malang: UIN Malang Press

Hafidhuddin, 2002. Didin. Zakat dalam Perekonomian Modern. Jakarta: Gema Insani

Hasbi Al-Furqon, 2008. 125 Masakah Zakat, Solo

Ismail Nawawi, 2010. Zakat Dalam Perspektif Fiwiq, Sosial dan ekonomi. Solo Mahfudh, Sahal. 2004. Nuansa Fiqh Sosial (Cetakan Ke-4). Yogyakarta: LKis Muhammad Hasan, 2011. Manajeman Zakat. Yogyakarta: Iedea Press Muhammad Manan, 1993. Teori dan Praktek Ekonomi Islam.

Muhammad Ridwan, 2005. Manajemen Perpajakan, ed.3 (Jakarta: Salemba Empat)

Sugiyono. Metode Penelitian Kuantitatif Kualitatif dan R \& D. 2015

M. Munir, dan Wahyu Illahi, 2009. Manajemen Dakwah, Jakarta: Kencana

Priyatno, Duwi. 2011. SPSS Analisis Statistik Data Lebih Cepat Lebih Akurat, Yogyakarta: Medikomm.

Qhardawi, Yusuf. 1993 Al-Ibadah Fi al-Islam. Mesir: Dar Fikr.

Qhardawi, Yusuf. 1996. Hukum Zakat, Bogor: Pustaka Liera Antar Nusa.

Qadir, Abdurahman, 1998, Zakat Dalam Dimensi Mahdhah dan Sosial, Jakarta: Raja Grafindo Persda

Zuhri, Saifudin. 2002. Zakat di Era Reformasi (Tata KelolaBaru) Undangundang Pengelolaan Zakat No 23 Tahun 2011. Semarang: Fakultas Tarbiyah IAIN Walisongo.

Website:

http://www.peduliberbagi.com/ di akses tanggal 15 September 2020 jam 09.15

41 | Vomule 2 Nomor 12019 
Cl, Mläl I Iurnal Kajian Ekonomi \& Bisnis Islam

Vol 2 No 1 (2019) 18-42 P-ISSN 2620-295 E-ISSN 2747-0490

DOI: 1047467/elmal.v1i1.313

https://www.daaruttauhiid.org/program/read/14/dompet-peduli-ummatdaarut-tauhiid.html diakses tanggal 17 September 2020 jam 11.36 